\title{
Prognostic significance and therapeutic implications of peroxisome proliferator-activated receptor $\gamma$ overexpression in human pancreatic carcinoma
}

\author{
YAN ZHANG $^{1,2^{*}}$, HUI-YAN LUO ${ }^{1,3^{*}}$, GUANG-LIN LIU $^{4}$, DE-SHEN WANG ${ }^{1}$, \\ ZHI-QIANG WANG ${ }^{1}$, ZHAO-LEI ZENG $^{1}$ and RUI-HUA XU ${ }^{1}$
}

\begin{abstract}
${ }^{1}$ State Key Laboratory of Oncology in South China, Sun Yat-sen University Cancer Center, Guangzhou 510060;
${ }^{2}$ Department of Medicine Oncology, The Sixth Affiliated Hospital of Sun Yat-sen University, Gastrointestinal and Anal Hospital of Guangdong Province, Guangzhou 510655; ${ }^{3}$ School of Engineering, Sun Yat-sen University, Guangzhou 510006; ${ }^{4}$ Department of Radiation Oncology, The First Affiliated Hospital of Guangzhou Medical College, Guangzhou 510120, P.R. China
\end{abstract}

Received August 13,2014; Accepted September 23, 2014

DOI: $10.3892 /$ ijo.2014.2709

\begin{abstract}
Peroxisome proliferator-activated receptor $\gamma$ $(\operatorname{PPAR} \gamma)$ is a ligand-activated nuclear receptor which has been implicated in carcinogenesis and angiogenesis in a wide range of cancers, including pancreatic carcinoma (PC). We aimed to characterize the prognosis and potential therapeutic implications of PPAR $\gamma$ in PC. Real-time RT-PCR and western blotting were used to quantify PPAR $\gamma$ expression in immortalized pancreatic epithelial cells, PC cell lines and freshly isolated matched tumor and non-tumor tissues. PPAR $\gamma$ protein expression was analyzed by immunohistochemistry (IHC) in archived tumor tissues from $101 \mathrm{PC}$ patients. Furthermore, the effect of PPAR $\gamma$ on the cytotoxic action of gemcitabine (Gem) and 5-fluorouracil (5-FU) in PC cell lines was investigated in vitro using RNA interference techniques. Both PPAR $\gamma$ protein and mRNA were expressed at markedly higher levels in all of the PC cell lines and freshly isolated PC tissues, compared to normal immortalized pancreatic epithelial cells and the matched adjacent non-tumor tissues. High levels of PPAR $\gamma$ expression correlated significantly with tumor-nodemetastasis $(\mathrm{TNM})$ staging $(\mathrm{P}<0.001)$ and poor overall survival $(\mathrm{P}<0.001)$, especially in patients with advanced disease who received postoperative chemotherapy. While silencing of $P P A R \gamma$ significantly inhibit the cytotoxic effects of both gemcitabine and 5-fluorouracil in PC cells in vitro. This study
\end{abstract}

Correspondence to: Dr Rui-Hua Xu, State Key Laboratory of Oncology in South China, Sun Yat-sen University Cancer Center, Guangzhou 510060, P.R. China

E-mail: xurh@sysucc.org.cn

*Contributed equally

Key words: PPAR $\gamma$, pancreatic cancer, prognosis, 5-fluorouracil, gemcitabine suggests that high levels of PPAR $\gamma$ expression are associated with poor overall survival in PC. Additionally, PPAR $\gamma$ promotes chemoresistance in PC cells, indicating that PPAR $\gamma$ may represent a novel therapeutic target for PC.

\section{Introduction}

Pancreatic cancer (PC) is the fourth-leading cause of cancer related mortality in the United States with a 5-year survival rate of $<7 \%$ (1-3). In 2012, >43,920 new cases of PC were estimated to be diagnosed and 37,390 deaths due to PC were expected in the United States (3). Despite recent progress in diagnosis and treatment, the prognosis of patients with PC still remains unsatisfactory and unpredictable, due to the invasive phenotype, early metastasis and high rate of resistance to existing chemo-radiotherapeutic strategies (4). Thus, identification of the biological changes that occur during the progression of PC, and the identification of novel markers of treatment sensitivity to more accurately predict clinical outcome will help to provide effective, individual treatment strategies for PC patients.

Numerous candidate genes have been screened in an attempt to specifically target pancreatic cancer cells and as therapeutic target genes, peroxisome-proliferator-activated receptor-gamma (PPAR $\gamma$ ) is one of them. PPAR $\gamma$ is a member of the PPAR nuclear receptor superfamily of ligand-activated transcription factors. Three subtypes of PPARs with different tissue distributions and ligand specificities have been identified: PPAR $\alpha, \operatorname{PPAR} \beta / \delta$ and PPAR $\gamma(5,6) . \operatorname{PPAR} \gamma$ is expressed at high levels in fat tissue and a number of other tissues, such as muscle, adrenal gland and liver (7-10), as well as endothelial cells $(11,12)$.

PPAR $\gamma$ is activated by the binding of specific ligands, and forms a complex with retinoid $\mathrm{X}$ receptors (13). The PPAR/ retinoid $\mathrm{X}$ receptor complex binds to specific peroxisome proliferator response elements (PPRE) which control the expression of a variety of target genes (14), to regulate cell proliferation, angiogenesis and inflammation (15-17). PPAR $\gamma$ is also required for adipogenesis, as it plays a key regulatory 
role in adipose cell differentiation and glucose homeostasis (18). Recent research revealed that PPAR $\gamma$ also participates in the biological mechanisms underlying carcinogenesis, including cancer cell proliferation and differentiation in vitro and in vivo $(19,20)$. PPAR $\gamma$ is overexpressed in a variety of human cancers, including PC, breast cancer, prostate cancer, non-small cell lung carcinoma and ovarian cancer (21-27).

In this study, we investigated the relationship between PPAR $\gamma$ expression and the clinicopathological features of PC, overall survival (OS) in PC, and chemoresistance in PC cells. Our results strongly suggest that PPAR $\gamma$ might be a potential therapeutic target for PC.

\section{Materials and methods}

Patients. In the present study, 101 PC patients who were histopathologically diagnosed after surgical resection at the Department of Gastrointestinal Surgery and Pathology (Sun Yat-sen University Cancer Center) from January 1999 to December 2010 were retrospectively enrolled. Gemcitabinebased chemotherapy was administered to the 44 patients with advanced-stage disease after surgery; none of the patients received radiotherapy. The clinicopathological features of the patient cohort are listed in Table I. All patients were followed-up on regular basis; last follow-up was May 2011 with a mean follow-up time of 19 months (range, 1-122 months), during which time 84 cancer-related deaths occurred. Four fresh PC and paired adjacent non-cancerous pancreatic tissues were collected for real-time quantitative polymerase chain reaction (qRT-PCR) and western blot analysis. All of the patients provided consent for the use of their paraffin embedded tissues for research purposes.

In order to use these clinical materials for researchpurposes, the patient's prior consent and approval from the Institutional Research Ethics Committee of the Sun Yat-sen University Cancer Center were obtained. Clinicopathological classification and staging were determined according to the criteria proposed by the American Joint Committee on Cancer and International Union Against Cancer criteria.

Cell lines and plasmids. The human immortalized pancreatic ductal epithelial cell line (IPEC) hTERT-HPNE E6/E7 and PC cell lines, including BxPc-3, Capan-2, SW1990, CFPAC-1 and PANC-1 were obtained from the American Type Culture Collection (Manassas, VA, USA). All cell lines were maintained in DMEM medium (Invitrogen, Carlsbad, CA, USA) supplemented with $10 \%$ fetal bovine serum (Hyclone, Logan, UT, USA).

For depletion of PPAR $\gamma$, two human short hairpin RNA (shRNA) sequences were individually cloned into the pSuperretro-neo plasmid to generate pSuper-retro-PPAR $\gamma$-RNAi(s), respectively; the sequences were RNAi\#1: GCGGAGATCTCC AGTGATATC and RNAi\#2: GCTGAATGTGAAGCCCAT TGA (synthesized by Invitrogen). Retroviral production and infection were performed as previously described (28). Stable cell lines expression PPAR $\gamma$ or PPAR $\gamma$ short hairpin RNAs (shRNA) were selected for 10 days with $0.5 \mu \mathrm{g} / \mathrm{ml}$ puromycin.

RNA extraction, reverse transcription and real-time PCR. Total RNA was extracted from cultured cells using TRIzol reagent (Invitrogen) following the manufacturer's instructions, and cDNA was amplified and quantified by quantitative real-time PCR (qRT-PCR) using the ABI PRISM 7500 Sequence Detection System (Applied Biosystems, Grand Island, NY, USA) with SYBR Green I (Molecular Probes, Grand Island, NY, USA). The qRT-PCR primers were selected as follows: PPAR $\gamma$, forward 5'-GAGTACCAAAGTGC AATCAAAGTG-3' and reverse 5'-TCTCCACAGACACGAC ATTC-3'. Expression data were normalized to the geometric mean of house-keeping gene GAPDH (forward: 5'-ACCACA GTCCATGCCATCAC-3' and reverse: 5'-TCCACCACCCTGT TGCTGTA-3') to control the variability in expression levels and calculated as, where $C_{t}$ represents the threshold cycle for each transcript.

Immunohistochemistry. Immunohistochemical analysis was performed to evaluate PPAR $\gamma$ protein expression in the 101 human fine-needle aspirations of PC tissues and 4 fresh pancreatic tissues. In brief, paraffin-embedded specimens were cut into $4-\mu \mathrm{m}$ sections, baked at $60^{\circ} \mathrm{C}$ for $2 \mathrm{~h}$, deparaffinized with xylene, rehydrated, subjected to antigen retrieval by microwaving in EDTA antigen retrieval buffer, and treated with $3 \%$ hydrogen peroxide in methanol to quench endogenous peroxidase activity, followed by $1 \%$ bovine serum albumin to block non-specific binding. The sections were incubated with rabbit anti-PPAR $\gamma$ (1:100; Santa Cruz Biotechnology, Santa Cruz, CA, USA) overnight at $4^{\circ} \mathrm{C}$. Normal goat serum was used as a negative control. After washing, the tissue sections were incubated with biotinylated anti-rabbit secondary antibody (Zymed, San Francisco, CA, USA) followed by streptavidin-horseradish peroxidase complex (Zymed). The sites of immunoreactivity were visualized using the 3.3'-diaminobenzidine (ZSGB-Bio, Beijing, China) and the sections were counterstained with 10\% Mayer's hematoxylin (SigmaAldrich, St. Louis, MO, USA), dehydrated and mounted.

PPAR $\gamma$ staining was scored as: i) the percentage of positive tumor cells in the tumor tissue $(0,1-5 \% ; 1,6-25 \% ; 2,26-50 \%$; $3,51-75 \% ; 4,76-100 \%)$ and ii) the staining intensity: (0, no signal; 1 , weak; 2 , moderate; 3 , strong). The immunoreactivity score (IRS) was calculated by multiplying the score for the percentage of positive cells and the intensity score (possible range, 0-7) (29). IRS scores $\geq 3$ were considered high expression. IHC staining was quantitatively analyzed using the Axio Vision Rel.4.6 computerized image analysis system assisted with an automatic measurement program (Carl Zeiss, Oberkochen, Baden-Württemberg, Germany). Briefly, the stained sections were evaluated at $\times 200$ magnification, and 10 representative stained fields in each section were analyzed to determine the mean optical density (MOD), which represents the strength of the staining signal as the percentage of positive pixels. The MOD data were analyzed using the t-test to compare the average MOD difference between different groups of tissues; $\mathrm{P}<0.05$ was considered statistically significant.

MTT assay. Cells were incubated at $37^{\circ} \mathrm{C}$ in an incubator with $5 \% \mathrm{CO}_{2}$. Cells at $0.2 \times 10^{4}$ of each line were seeded in a 96 -well microtiter plate and allowed to adhere to the plate for $24 \mathrm{~h}$ at $37^{\circ} \mathrm{C}$. Cells were then treated for $72 \mathrm{~h}$ at $37^{\circ} \mathrm{C}$ with either gemcitabine (EliLilly and Co., Indianapolis, IN,USA) or 5-fluorouracil (5-FU) (Sigma-Aldrich) with or without Pioglitazone 
Table I. Correlation between PPAR $\gamma$ expression and clinicopathological characteristics of PC.

\begin{tabular}{|c|c|c|c|c|}
\hline \multirow[b]{2}{*}{ Clinical parameter } & \multicolumn{4}{|c|}{ All cases } \\
\hline & $\begin{array}{c}\text { Cases }(\mathrm{N}=101) \\
\mathrm{n}(\%)\end{array}$ & $\begin{array}{c}\text { PPAR } \gamma^{-}(\mathrm{N}=27) \\
\mathrm{n}(\%)\end{array}$ & $\begin{array}{c}\mathrm{PPAR} \gamma^{+}(\mathrm{N}=74) \\
\mathrm{n}(\%)\end{array}$ & P-value ${ }^{a}$ \\
\hline \multicolumn{5}{|l|}{ Age (years) } \\
\hline$\geq 65$ & $49(48.5)$ & $15(55.6)$ & $34(45.9)$ & 0.392 \\
\hline$<65$ & $52(51.5)$ & $12(44.4)$ & $40(54.1)$ & \\
\hline \multicolumn{5}{|l|}{ Gender } \\
\hline Male & $57(56.4)$ & $16(59.3)$ & $41(55.4)$ & 0.730 \\
\hline Female & $44(43.6)$ & $11(40.7)$ & $33(44.6)$ & \\
\hline \multicolumn{5}{|l|}{ Clinical stage } \\
\hline I & $21(20.8)$ & $11(40.7)$ & $10(13.5)$ & 0.004 \\
\hline II & $53(52.5)$ & $10(37.0)$ & $43(58.1)$ & \\
\hline III & $15(14.9)$ & $1 \quad(3.7)$ & $14(18.9)$ & \\
\hline IV & $12(11.9)$ & $5(18.5)$ & $7 \quad(9.5)$ & \\
\hline \multicolumn{5}{|l|}{$\mathrm{T}$ classification } \\
\hline $\mathrm{T} 1$ & $5 \quad(5.0)$ & $3(11.1)$ & $2(2.7)$ & 0.002 \\
\hline $\mathrm{T} 2$ & $26(25.7)$ & $13(48.1)$ & $13(17.6)$ & \\
\hline $\mathrm{T} 3$ & $54(53.5)$ & $10(37.0)$ & $44(59.5)$ & \\
\hline $\mathrm{T} 4$ & $16(15.8)$ & $1 \quad(3.7)$ & $15(20.3)$ & \\
\hline \multicolumn{5}{|l|}{$\mathrm{N}$ classification } \\
\hline NO & $63(62.4)$ & $12(44.4)$ & $51(68.9)$ & 0.025 \\
\hline N1 & $38(37.6)$ & $15(55.6)$ & $23(31.1)$ & \\
\hline \multicolumn{5}{|l|}{ Pathologic differentiation } \\
\hline Well & $8 \quad(7.9)$ & $5(5.0)$ & $3(4.1)$ & 0.151 \\
\hline Moderate & $39(38.6)$ & $11(40.7)$ & $28(37.8)$ & \\
\hline Poor and undifferentiated & $54(53.5)$ & $11(40.7)$ & $43(58.1)$ & \\
\hline \multicolumn{5}{|c|}{ Chemotherapy regimen after surgery } \\
\hline Yes & $44(43.6)$ & $10(46.0)$ & $34(41.2)$ & 0.123 \\
\hline No & $57(56.4)$ & $17(54.0)$ & $40(58.8)$ & \\
\hline
\end{tabular}

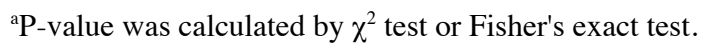

(Pio, Takeda Pharmaceutical Co. Ltd., Osaka, Japan) at various concentrations, as indicated in the figure legends. At the appropriate time-points, the cells were incubated with $100 \mu 1$ 3-(4,5-dimethylthiazol-2-yl)-2,5-diphenyltetrazolium bromide (MTT) dye $(0.5 \mathrm{mg} / \mathrm{ml}$; Sigma-Aldrich) for $4 \mathrm{~h}$, the culture medium was removed and $150 \mu \mathrm{l}$ of dimethyl sulfoxide (DMSO) (Sigma-Aldrich) was added to dissolve the formazan crystals. The absorbance values were measured by Spectra Max M5 spectrometer (Molecular Devices, Sunnyvale, CA, USA) at $570 \mathrm{~nm}$, with $630 \mathrm{~nm}$ as the reference wavelength. All experiments were carried out in triplicate. In MTT assay, there is a linear relationship between the OD reading and the number of viable cells. Percent drug killing of cancer cells $=\left(\mathrm{OD}_{\text {control well }}-\mathrm{OD}_{\text {drug-exposed well }}\right) /\left(\mathrm{OD}_{\text {control well }}-\mathrm{OD}_{\text {blank well }}\right)$ $\mathrm{x} 100 \%$. The average OD readings were obtained from 3 duplicate wells in any one MTT assay, all experiments were carried out in triplicate.

Flow cytometry analysis. Early and late cell apoptosis was measured by flow cytometry using Annexin V and PI provided in a commercial kit (Biovision, Zurich, Switzerland) according to the manufacturer's protocol. Briefly, the cells were seeded in a 6 -well plate at a density of $1 \times 10^{6}$ cells/well and remained in spontaneous culture media at $37^{\circ} \mathrm{C}$ with $5 \% \mathrm{CO}_{2}$ for $24 \mathrm{~h}$ at $37^{\circ} \mathrm{C}$. Then the cells were treated for $48 \mathrm{~h}$ at $37^{\circ} \mathrm{C}$ with either gemcitabine or 5-fluorouracil with or without Pio at various concentrations as indicated in the figure legends. On the test day, $1 \times 10^{5}$ trypsinized cells were washed twice in PBS and resuspended in $100 \mu \mathrm{l}$ of binding buffer, then suspended in Annexin V-binding buffer, stained with Annexin V-FITC for $15 \mathrm{~min}$ at room temperature, washed and stained with PI. The samples were analyzed using a FACSCalibur flow cytometer equipped with CellQuest-Pro software (Becton-Dickinson, San Jose, CA, USA).

Western blotting. The fresh tissues were ground to a powder in liquid nitrogen, lysed with sampling buffer [62.5 mmol/1 Tris- $\mathrm{HCl}$ (pH 6.8), 2\% SDS, $10 \%$ glycerol and $5 \%$ 2- $\beta$-mercaptoethanol], and the protein concentrations were determined using the Bradford assay (Bio-Rad 
Laboratories, Berkeley, CA, USA). Equal amounts of protein were electrophoretically separated on $9 \%$ polyacrylamide SDS gels (SDS-PAGE) and transferred to polyvinylidene fluoride membranes (Amersham Pharmacia Biotech, QC, Canada). The membranes were incubated with an anti-PPAR $\gamma$ mouse antibody (1:100; Santa Cruz Biotechnology), followed by a horseradish peroxidase-conjugated anti-mouse $\operatorname{IgG}$ antibody (1:2,000; Amersham Pharmacia Biotech) and the bands were detected using an enhanced chemiluminescence kit (Amersham Pharmacia Biotech) according to the manufacturer's instructions. The membranes were subsequently stripped and re-probed with an anti-tubulin mouse monoclonal antibody (1:2,000; Sigma-Aldrich) as a loading control.

Statistical analysis. All statistical analyses were carried out using SPSS version 13.0 (SPSS, Chicago, IL, USA). Comparisons between groups were performed using two-tailed paired Student's t-tests. The relationships between PPAR $\gamma$ expression and the patient clinicopathological features were analyzed using the $\chi^{2}$ test. Survival curves were plotted by the Kaplan-Meier method and compared using the log-rank test. Survival data were evaluated using univariate and multivariate Cox regression analyses. P-values $<0.05$ were considered statistically significant for all analyses.

\section{Results}

Association between PPAR $\gamma$ and clinical stage in PC. The association between PPAR $\gamma$ expression level and clinicopatholigical characteristics in PC patients was studied. PPAR $\gamma$ expression was examined in 101 fine-needle aspirations of $\mathrm{PC}$ tissues, including 21 cases of clinical stage I (20.8\%), 53 cases of stage II (52.5\%), 15 cases of stage III (14.9\%) and 12 cases of stage IV (11.9\%) PC. Significant correlation was observed between PPAR $\gamma$ expression level and several prognostic risk factors such as clinical stage, $\mathrm{T}$ classification and $\mathrm{N}$ classification (Table I). PPAR $\gamma$ immunostaining was localized in the nucleus. The IHC analysis demonstrated that PPAR $\gamma$ was markedly upregulated in PC tissues, but it was only marginally detectable or not at all in normal pancreatic tissues $(\mathrm{P}<0.05$, Fig. 1A). Quantitative analysis of the IHC staining using the MOD scores indicated that PPAR $\gamma$ expression in clinical stage I to stage IV primary PC was significantly higher than normal pancreatic tissues $(\mathrm{P}<0.05$, Fig. 1B).

High PPAR $\gamma$ expression is associated with poor prognosis in PC, especially in patients with advanced disease who received postoperative chemotherapy. The PC patients were divided into two groups: high and low PPAR $\gamma$ expression based on the IRS score determined during IHC analysis (high $=$ IRS score $\geq 4$ ). Kaplan-Meier and log-rank analysis demonstrated a significant difference in the overall survival time of patients with low and high PPAR $\gamma$ expression. High PPAR $\gamma$ expression was closely associated with poor overall survival $(\mathrm{P}<0.001$, Fig. 2A). Furthermore, high PPAR $\gamma$ expression correlated strongly with poor overall survival in the subsets of patients with $\mathrm{T} 3+\mathrm{T} 4$ disease or $\mathrm{N} 0$ disease (both $\mathrm{P}<0.001$; Fig. 2B and C). Interestingly, high PPAR $\gamma$ protein expression also correlated significantly with poorer overall survival in patients who received postoperative treatment for advanced
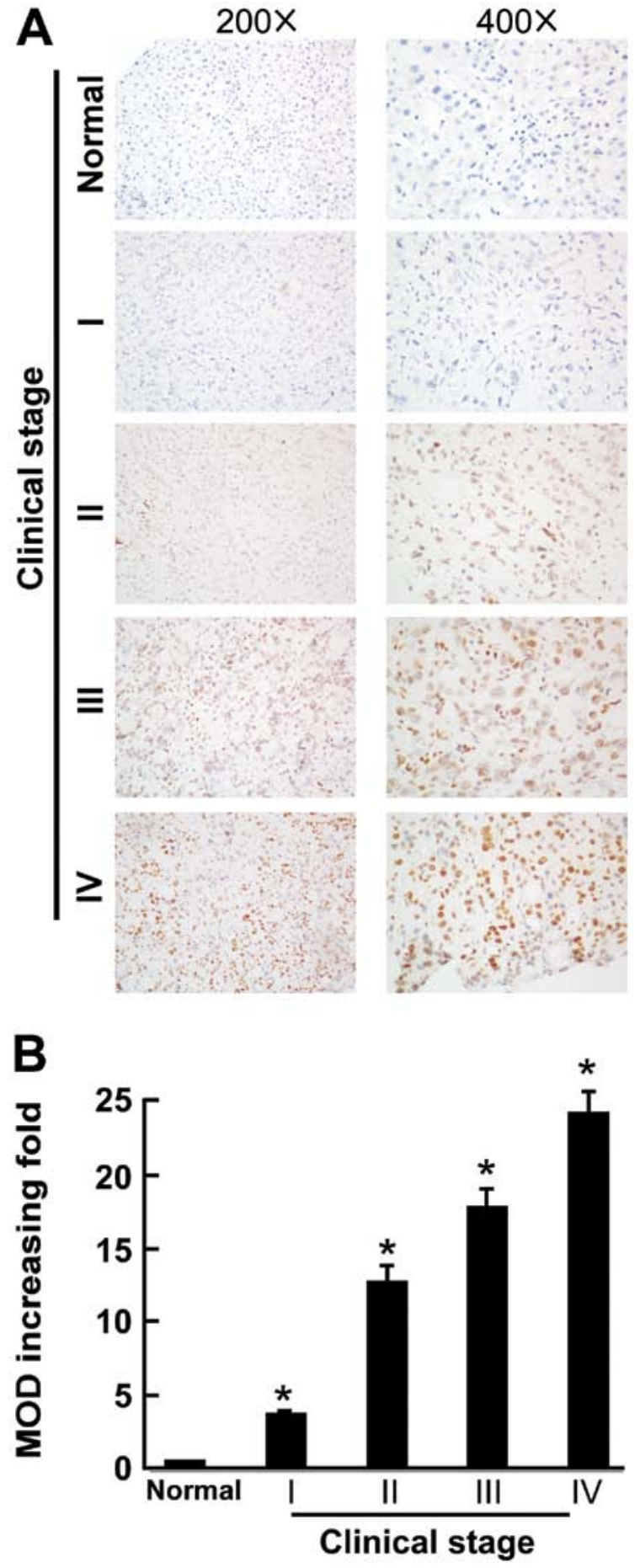

Figure 1. Expression of PPAR $\gamma$ correlates with clinical stage in pancreatic cancer (PC). Representative immunohistochemical (IHC) analyses of PPAR $\gamma$ expression in normal pancreatic tissues and PC specimens of different clinical stages. (B) Average optical density (MOD) for PPAR $\gamma$ staining in normal pancreatic tissues and pancreatic cancer specimens of different clinical stages. The average PPAR $\gamma$ MOD value increased with clinical stage; ${ }^{*} \mathrm{P}<0.01$.

disease $(\mathrm{P}<0.001$, Fig. 2D). PPAR $\gamma$ protein expression correlated significantly with the clinical stage, $\mathrm{T}$ classification, $\mathrm{N}$ classification, overall survival and survival of patients with chemotherapy regimen after surgery (Table II). Moreover, univariate and multivariate analyses revealed that clinical stage, the T classifications and PPAR $\gamma$ expression were each 

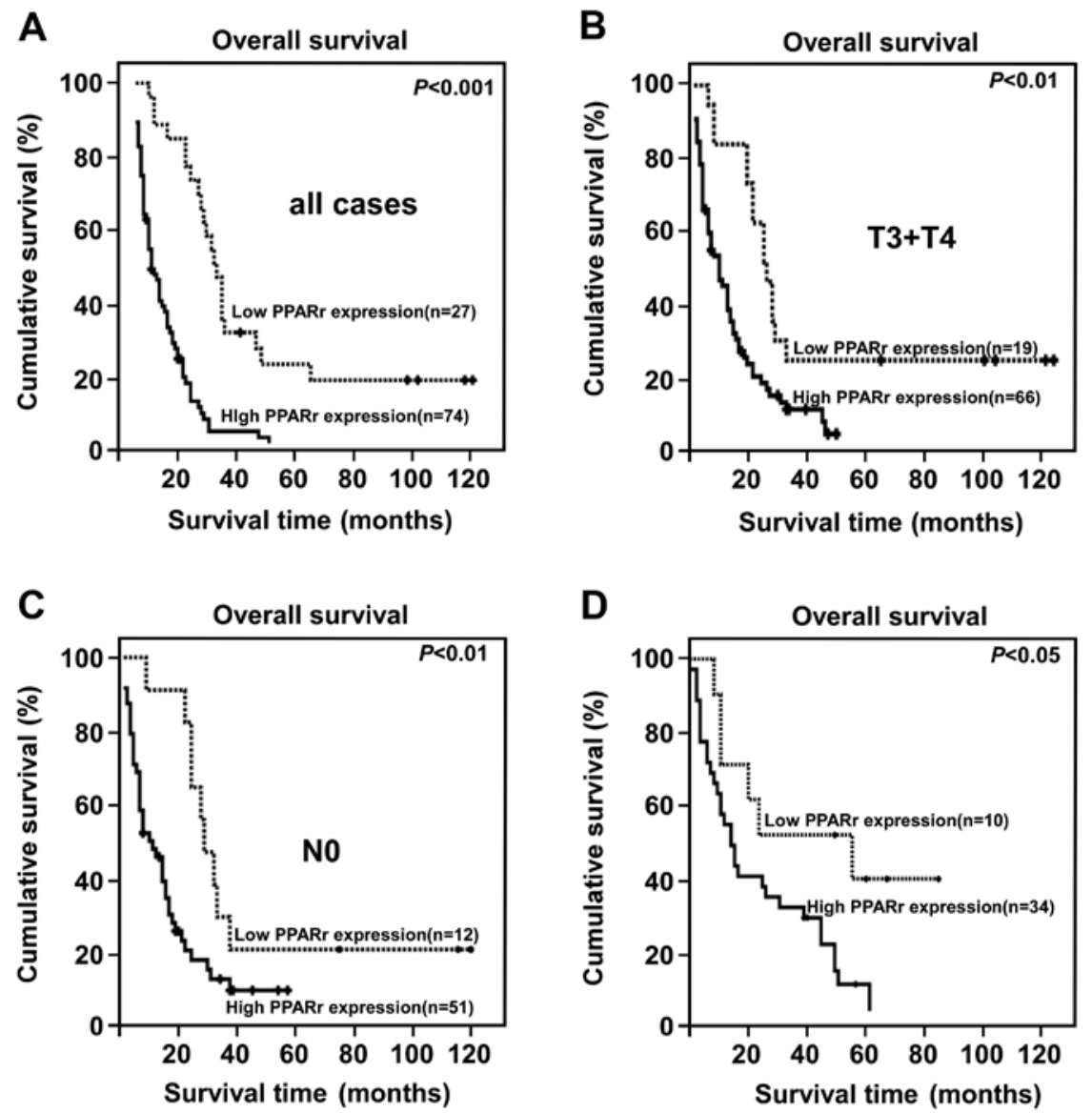

Figure 2. Influence of PPAR $\gamma$ on overall survival in pancreatic cancer (PC). Kaplan-Meier analysis showed that high PPAR $\gamma$ expression was associated with poorer overall survival in (A) the entire cohort of 101 primary PC patients $(\mathrm{P}<0.001)$; (B) the subset of patients with T3+T4 disease $(\mathrm{P}<0.001)$; $(\mathrm{C})$ the subset of patients with N0 disease $(\mathrm{P}<0.001)$; and $(\mathrm{D})$ the subset of patients with advanced disease who received postoperative chemotherapy $(\mathrm{P}<0.001)$.

Table II. Spearman correlation analysis between PPAR $\gamma$ and clinical pathologic factors.

\begin{tabular}{lcc}
\hline & \multicolumn{2}{c}{ PPAR $\gamma$ expression level } \\
\cline { 2 - 3 } Variables & Spearman correlation & P-value \\
\hline Clinical staging & 0.256 & 0.006 \\
T classification & 0.281 & 0.001 \\
N classification & 0.193 & 0.010 \\
Survival & -0.249 & 0.010 \\
Pathologic differentiation & 0.114 & 0.065 \\
Survival of patients with & -0.189 & 0.035 \\
chemotherapy regimen & & \\
after surgery & & \\
\hline
\end{tabular}

recognized as independent prognostic factors (Table III), suggesting that PPAR $\gamma$ expression can be utilized as a predictor of survival in PC patients, and also that patients with low levels of PPAR $\gamma$ expression might experience greater benefit from adjuvant therapy.

PPAR is upregulated in human pancreatic cancer. To investigate the potential role of PPAR $\gamma$ in the progression of PC,
Western blotting, qRT-PCR and IHC analyses were performed on PC cell lines (BxPc-3, Capan-2, SW 1990, CFPAC-1, PANC-1), immortalized pancreatic epithelial cells (IPECs) and four freshly isolated PC tissues and the paired adjacent non-cancerous tissues. As shown in Fig. 3A and B both PPAR $\gamma$ mRNA and protein were markedly upregulated in all of the PC cell lines tested, compared with IPECs. The expression of PPAR $\gamma$ mRNA was 4- to 10-fold higher in PC tissues than the adjacent non-tumor tissues (Fig. 3C). Furthermore, comparative analysis revealed that PPAR $\gamma$ protein expression was upregulated in all four of the freshly isolated PC tissues, compared with the matched adjacent non-tumor tissues (Fig. 3D) suggesting that PPAR $\gamma$ is overexpressed in PC.

Silencing of PPAR $\gamma$ decreases the chemosensitivity of PC cells in vitro. To investigate the impact of PPAR $\gamma$ on the efficacy of chemotherapy in PC, we used PPAR $\gamma$ ligand pioglitazone and two short hairpin RNAs for $P P A R \gamma$ was employed to suppress endogenous $P P A R \gamma$ expression stably in BxPc-3 and PANC-1 cell lines. Western blot analysis revealed that the amount of PPAR $\gamma$ protein in PPAR $\gamma$ RNAi(s) cells, normalized by $\alpha$-tubulin, was reduced up to $80 \%$ compared with PPAR $\gamma$ RNAi-vector cells (Fig. 4A). The PANC-1 and BxPc-3 cells were exposed to Gem alone or Gem plus PPAR $\gamma$ ligand (10 $\mu \mathrm{M}$ Pio) with or without PPAR $\gamma$ knockdown. After 72-h treatment, greater apoptosis was observed in the cells treated 
Table III. Univariate and multivariate analyses of various prognostic parameters in patients with PC Cox-regression analysis.

\begin{tabular}{|c|c|c|c|c|c|c|}
\hline & \multicolumn{3}{|c|}{ Univariate analysis } & \multicolumn{3}{|c|}{ Multivariate analysis } \\
\hline & $\begin{array}{l}\text { No. of } \\
\text { patients }\end{array}$ & P-value & $\begin{array}{c}\text { Regression } \\
\text { coefficient (SE) }\end{array}$ & P-value & $\begin{array}{l}\text { Relative } \\
\text { risk }\end{array}$ & $\begin{array}{c}95 \% \text { confidence } \\
\text { interval }\end{array}$ \\
\hline \multicolumn{7}{|l|}{ Clinical stage } \\
\hline I & 21 & 0.000 & $0.512(0.027)$ & 0.001 & 1.669 & $1.227-1.971$ \\
\hline II & 53 & & & & & \\
\hline III & 15 & & & & & \\
\hline IV & 12 & & & & & \\
\hline \multicolumn{7}{|l|}{$\mathrm{T}$ classification } \\
\hline $\mathrm{T} 1$ & 5 & 0.000 & $0.706(0.197)$ & 0.001 & 1.521 & $1.239-2.015$ \\
\hline $\mathrm{T} 2$ & 26 & & & & & \\
\hline $\mathrm{T} 3$ & 54 & & & & & \\
\hline $\mathrm{T} 4$ & 16 & & & & & \\
\hline \multicolumn{7}{|c|}{ Expression of PPAR $\gamma$} \\
\hline Low expression & 44 & 0.023 & $0.239(0.019)$ & 0.030 & 1.227 & $1.046-1.576$ \\
\hline High expression & 57 & & & & & \\
\hline
\end{tabular}

PPAR $\gamma$ protein expression level in pancreatic cancer significantly correlated with patient survival time $(\mathrm{P}=0.000)$. The correlation coefficient was 0.239 , and the relative risk (RR) was 1.227 , indicating that higher levels of PPAR $\gamma$ expression correlated with lower death rate.

A

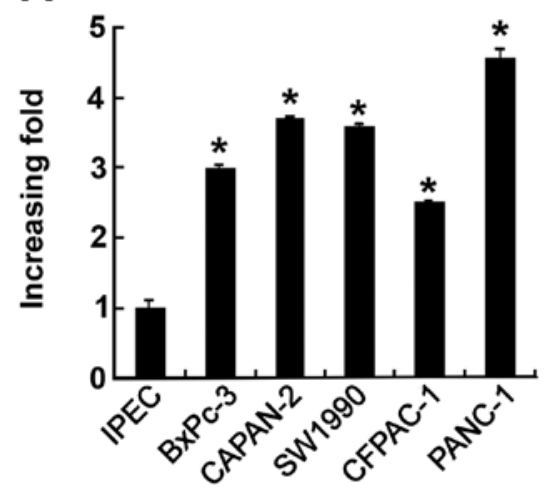

B

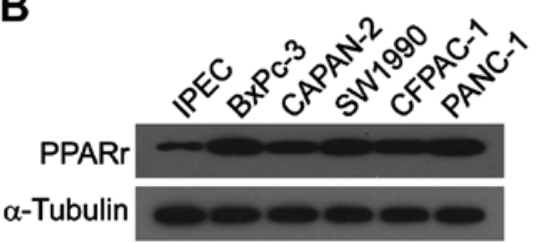

C

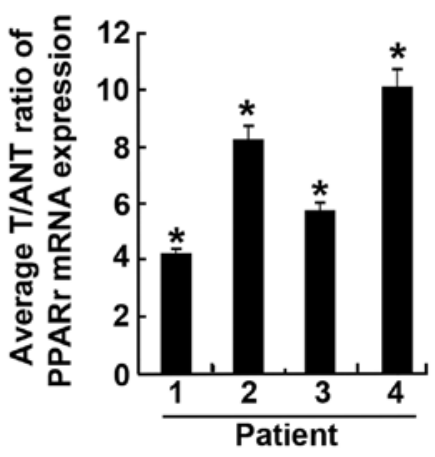

D

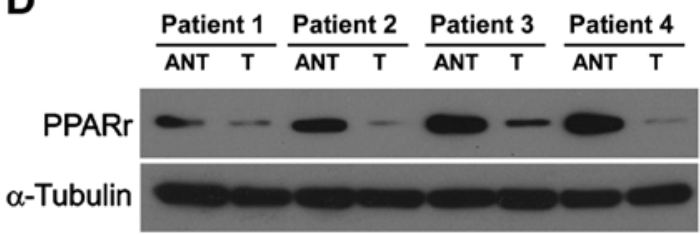

Figure 3. PPAR $\gamma$ is upregulated in human pancreatic cancer (PC). (A) Expression of PPAR $\gamma$ mRNA in immortalized pancreatic epithelial cells (IPECs) $(\mathrm{n}=2)$ and cultured PC cell lines $(\mathrm{n}=5) . P P A R \gamma$ was normalized to $G A P D H$. Values are the mean $\pm \mathrm{SD}$ of three independent $\mathrm{qRT}-\mathrm{PCR}$ experiments; ${ }^{*} \mathrm{P}<0.05$. (B) Western blot analysis of PPAR $\gamma$ expression in IPEC and cultured PC cell lines ( $\mathrm{n}=5$ ); $\alpha$-tubulin was used as a loading control. (C) qRT-PCR analysis of PPAR $\gamma$ mRNA expression in paired primary PC tissues $(\mathrm{T})$ and the adjacent non-cancerous tissues $(\mathrm{ANT})$ from the same patients $(\mathrm{n}=4)$. Values are the mean $\pm \mathrm{SD}$ of three independent experiments; ${ }^{*} \mathrm{P}<0.05$. (D) Western blot analysis of PPAR $\gamma$ protein expression in $\mathrm{T}$ and $\mathrm{ANT}$.

with Gem plus PPAR $\gamma$ ligand, compared with the cells treated with Gem alone. The PPAR $\gamma$-RNAi(s) cells treated with Gem plus PPAR $\gamma$ ligand showed minimal apoptosis, compared with the vehicle treated with Gem alone or Gem plus PPAR $\gamma$ ligand. Similar results were observed in the cells exposed to 5-FU alone or 5-FU plus PPAR $\gamma$ ligand (10 $\mu \mathrm{M}$ Pio) with or without PPAR $\gamma$ knockdown (Fig. 4B). As shown in Fig. 4C, silencing of endogenous $P P A R \gamma$ increased Gem plus Pio $\mathrm{IC}_{50}$ values 3.5- and 1.7-fold for Panc-1 and BxPc-3 cells, increased 5-FU plus Pio $\mathrm{IC}_{50}$ values 2.6- and 2.4-fold, respectively. Futhermore, the PPAR $\gamma$-RNAi(s) cells Gem or 5-FU plus Pio $\mathrm{IC}_{50}$ values significantly lower than the vector cells incubated 
A

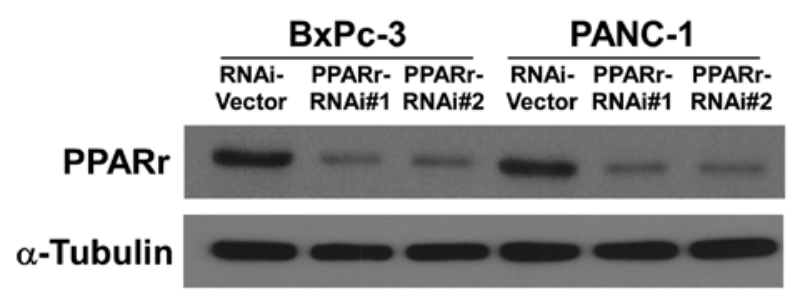

B

$\longrightarrow$ Vector treated with Gem/5-Fu

- - Vector treated with Gem/5-Fu + Pio

- - PPARr-RNAi1 treated with Gem/5-Fu + Pio

- PPARr-RNAi2 treated with Gem/5-Fu + Pio
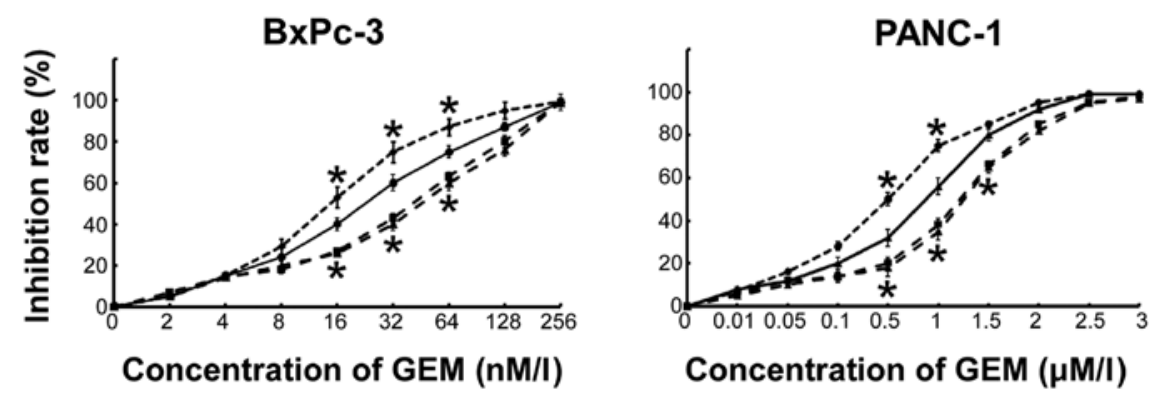

Concentration of GEM $(\mu \mathrm{M} / \mathrm{I})$
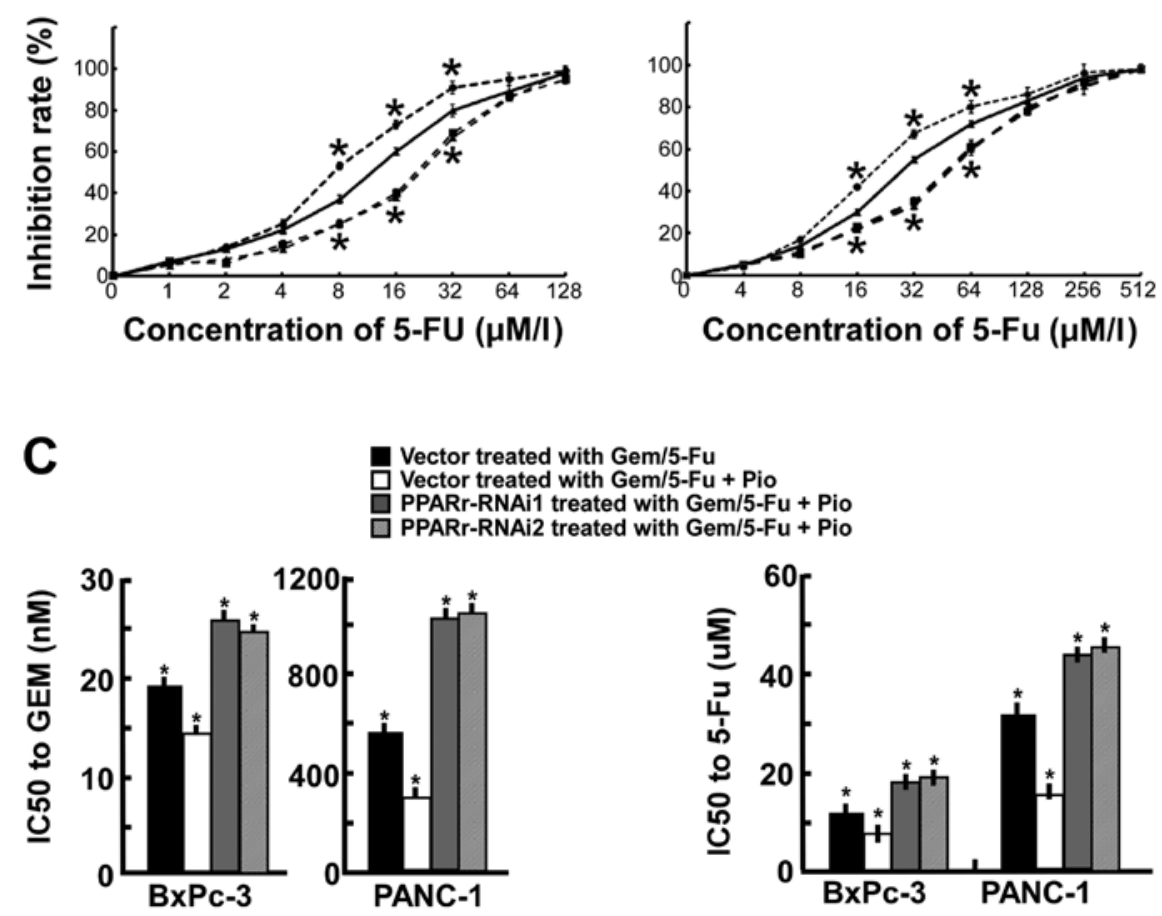

Figure 4. Silencing of PPAR $\gamma$ decreases the chemosensitivity of gemcitabine and 5-FU in pancreatic cancer (PC) cells. (A) Knockdown of PPAR $\gamma$ in specific shRNA-transduced stable PC cell lines $(\mathrm{n}=2)$. $\alpha$-tubulin was used as a loading control. (B) Effect of silencing PPAR $\gamma$ on the viability of BxPc-3 and PANC-1 cells. Cells were cultured in 96-well plates, transfected with siRNA to silence PPAR $\gamma$, incubated for $24 \mathrm{~h}$, treated with the indicated drugs with or without Pio $10 \mu \mathrm{M}$ for $72 \mathrm{~h}$, then cell viability was measured using the MTT assay. Data are representative of three independent experiments; ${ }^{*}<0.05$. (C) Effect of silencing PPAR $\gamma$ on the $\mathrm{IC}_{50}$ values for gemcitabine and 5-FU with or without Pio in PANC-1 and BxPc-3 cells at $72 \mathrm{~h}$. Values are the mean $\pm \mathrm{SE}$ of three independent experiments.

with Gem or 5-FU alone $(\mathrm{P}<0.01)$. These results indicate that downregulation of PPAR $\gamma$ decreased the cytotoxic effects of Gem and 5-FU in pancreatic cancer cells.

Silencing of PPAR inhibited apoptosis of PC cells in vitro. As shown in Fig. 5A-D, downregulated of $P P A R \gamma$ inhibited the percentage of apoptotic PANC-1 cells after the cells were treated in $500 \mathrm{~nm}$ Gem plus $10 \mu \mathrm{M}$ Pio for $48 \mathrm{~h}$, compared with the PPAR $\gamma$-RNAi vector cells treated with Gem alone or Gem plus Pio, respective $(\mathrm{P}<0.01)$. Similarly, the apoptosis rate of the PANC-1 PPAR $\gamma$-RNAi(s) cells treated with 5-FU $(40 \mu \mathrm{M})$ plus Pio $(10 \mu \mathrm{M})$ clearly lower than the PPAR $\gamma$ vector cells treated with 5-FU plus Pio or with 5-FU alone, which were $(3.7 \pm 0.3,4.0 \pm 0.5),(33.0 \pm 1.8)$ and $(18.2 \pm 2.2) \%$, 
PANC-1
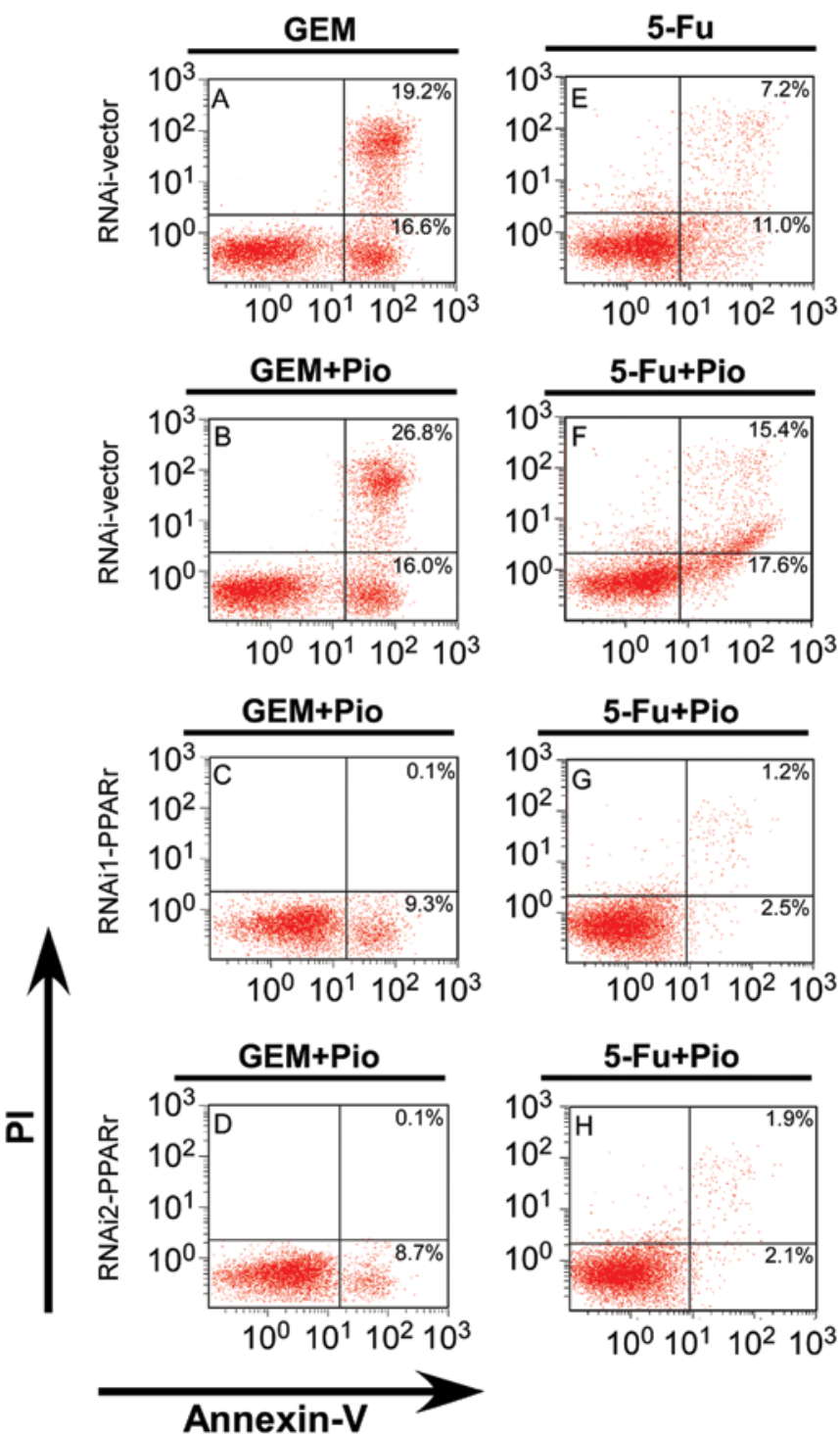

Figure 5. Silencing of $P P A R \gamma$ decreases the pro-apoptotic effects of gemcitabine and 5-FU with or without PPAR $\gamma$ ligand in PANC-1 cells. (A-D) PANC-1 PPAR $\gamma$ RNAi-vector cells, PANC-1 PPAR $\gamma$ RNAi(s) cells were incubated for $24 \mathrm{~h}$, treated with $500 \mathrm{nM}$ Gem with or without $10 \mu \mathrm{M}$ Pio for $48 \mathrm{~h}$, then stained with Annexin V and PI and subjected to FACS analysis to determine the percentage of apoptotic cells. Data are representative of three independent experiments. The lowest left quadrant shows live cells (Annexin V-negative and PI-negative); the lowest right quadrant, early apoptotic cells (Annexin V-positive and PI-negative); top right quadrant, late apoptotic or necrotic cells (PI-positive and Annexin V-positive). (E-H) PANC-1 PPAR $\gamma$ RNAi-vector cells, PANC-1 PPAR $\gamma$ RNAi(s) cells treated with $40 \mu \mathrm{M} 5-\mathrm{FU}$ with or without $10 \mu \mathrm{M}$ Pio for $48 \mathrm{~h}$.

respectively $(\mathrm{P}<0.01$, Fig. 5E-H). Similar situation appeared when BxPc-3 PPAR $\gamma$-RNAi(s) cells and PPAR $\gamma$-RNAi vector cells were treatment with drugs: the precentage of early and late apoptotic BxPc-3 PPAR $\gamma$-RNAi(s) cells treated with Gem/5-FU plus Pio were clearly lower than the PPAR $\gamma$-vector cells, also lower than the PPAR $\gamma$-vector cells treated with Gem/5-FU alone ( $\mathrm{P}<0.01$, Fig. 6). These results indicate that downregulation of PPAR $\gamma$ decreased the antitumor effects on pancreatic cancer cells and is a potent apoptosis inhibitor.

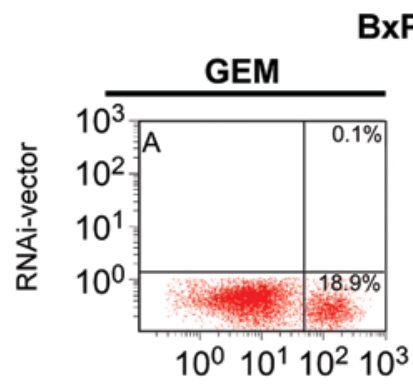

BxPc-3
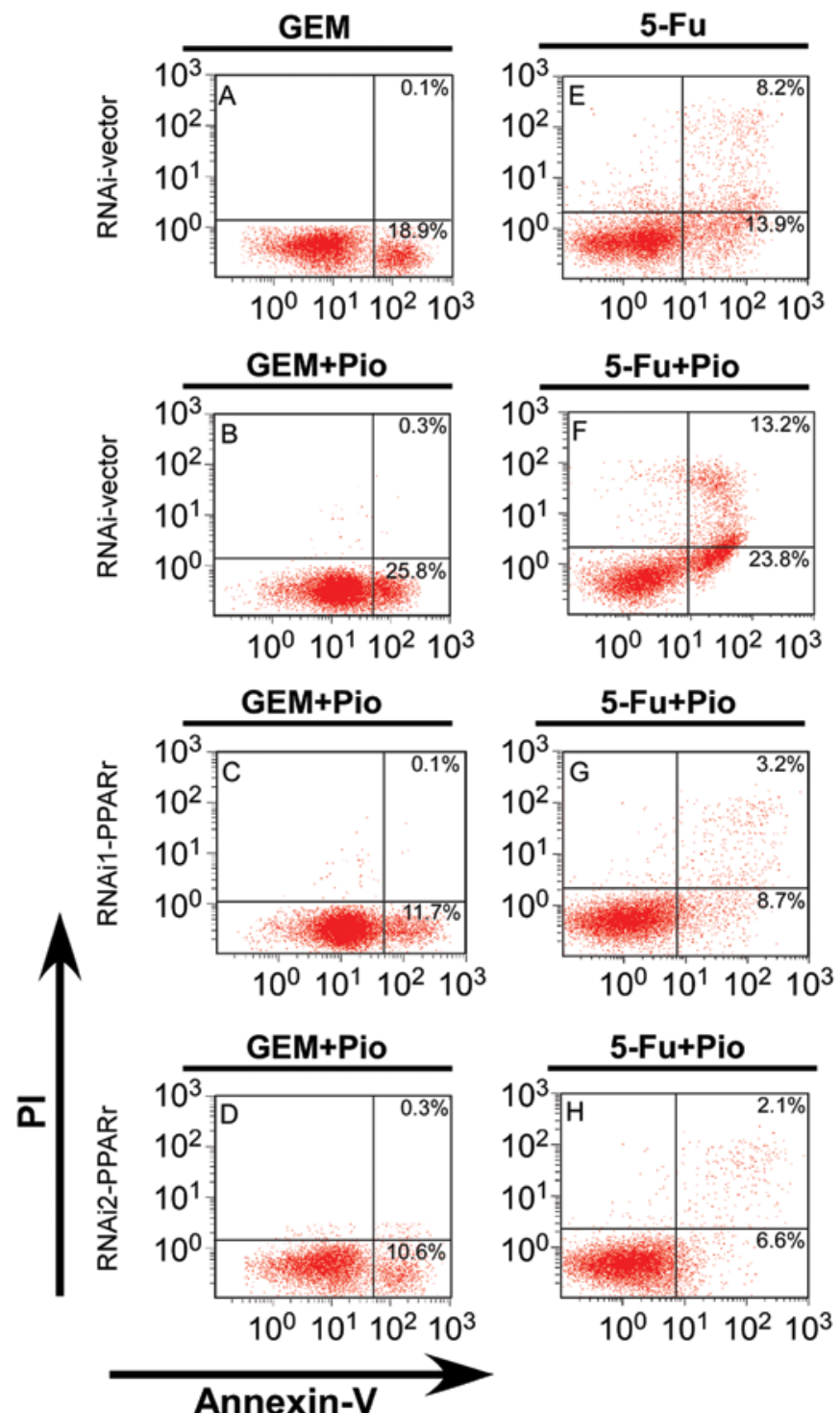

Figure 6. Silencing of PPAR $\gamma$ decreases the pro-apoptotic effects of gemcitabine and 5-FU with or without PPAR $\gamma$ ligand in BxPc-3 cells. (A-D) BxPc-3 PPAR $\gamma$ RNAi-vector cells, BxPc-3 PPAR $\gamma$ RNAi cells were incubated for $24 \mathrm{~h}$, treated with $500 \mathrm{nM}$ Gem with or without $10 \mu \mathrm{M}$ Pio for $48 \mathrm{~h}$, then stained with Annexin V and PI and subjected to FACS analysis to determine the percentage of apoptotic cells. Data are representative of three independent experiments. The lowest left quadrant shows live cells (Annexin V-negative and PI-negative); the lowest right quadrant, early apoptotic cells (Annexin V-positive and PI-negative); top right quadrant, late apoptotic or necrotic cells (PI-positive and Annexin V-positive). (E-H) BxPc-3 PPAR $\gamma$ RNAi-vector cells, BxPc-3 PPAR $\gamma$ RNAi(s) cells treated with $40 \mu \mathrm{M} 5$-FU with or without $10 \mu \mathrm{M}$ Pio for $48 \mathrm{~h}$.

\section{Discussion}

PPAR $\gamma$ is known to be overexpressed in various tumors, including hematologic malignancies $(30,31)$ and solid tumors (32-36). The expression of PPAR $\gamma$ has previously been reported in PC cell lines and tissues, including SUIT-2, AsPC-1, BxPC-3, Capan-2, HPAF-II, MIA Paca-2 and PANC-1 cells (27,37-39). Sasaki et al found that PPAR $\gamma$ mRNA was expressed in five of seven human PC samples, whereas PPAR $\gamma$ expression was not detected in the adjacent normal tissues (27). Itami et al 
conducted immunohistochemistry and demonstrated that $75 \%$ of 47 primary PC tissues and $80 \%$ of 15 liver PC metastases expressed high levels of PPAR $\gamma$ (39). The findings of our study are in agreement with these results, as we observed that PPAR $\gamma$ mRNA and protein were overexpressed in PC cell lines and primary PC tissues, compared to IPECs and the paired adjacent non-cancerous tissues. PPAR $\gamma$ has previously been associated with shorter overall survival in PC (22). Our study confirms this result, especially in patients with advanced disease who received postoperative chemotherapy.

PPAR $\gamma$ can regulate cell proliferation, angiogenesis and inflammation (15-17). Previous in vitro studies have suggested that PPAR $\gamma$ plays an important role in PC. Eibl et al reported that PPAR $\gamma$ agonists time- and dose-dependently decreased the viability of PC cell lines (37). Kristiansen et al found that PPAR $\gamma$ is highly expressed in PC and is associated with shorter overall survival times (22). Our conclutions are consistent with this. More importantly, we demonstrated that PPAR $\gamma$ may play an important role in gemcitabine and 5-FU effect of PC patients, because for the patients with advanced PC who received postoperative chemotherapy, increased expression of PPAR $\gamma$ associated with poor prognosis.

Gemcitabine and 5-FU are the most commonly used chemotherapeutic agent for PC; however, the clinical benefits of these drugs are not obvious $(40,41)$. The poor response to chemotherapy in PC patients may due to inherent chemoresistance of PC cells and impaired drug delivery pathways (42). There has been some research on the resistance aspects of gemcitabine and 5-FU. Leung et al found that suppression of Lipocalin2 (LCN2) in PC cells increased their sensitivity to gemcitabine in vitro, and in vivo (43). Awasthi et al reported that insulin-like growth factor (IGF) signaling proteins are frequently overexpressed in pancreatic duct adenocarcinoma (PDAC), and using a small molecular inhibitor of IGF receptor (BMS-754807) was able to enhance gemcitabine response in PC (44). Wang et al reported that the proliferation was inhibited more significantly in MIA Paca-2 and PANC-1 cells when treated with Ad-PUMA combined with anticancer drugs (cDDP, 5-FU, Gem) than when treated with anticancer drugs alone (45).

Our data demonstrated that for the patients with advanced PC who received postoperative chemotherapy including gemcitabine and 5-FU, increased expression of PPAR $\gamma$ associated with poor prognosis. Next, we examined the functional involvement of the PPAR $\gamma$ in Gem or 5-FU induced apoptosis using PPAR $\gamma$ ligand pioglitazone and PPAR $\gamma$-RNAi(s) cells. The cell function results and the clinical data appears to be inconsistent, because our in vitro results suggest that PPAR $\gamma$ increased sensitivity of chemotherapy in PC cells. Silencing of $P P A R \gamma$ significantly declined the chemosensitivity of PANC-1 and $\mathrm{BxPc}-3$ cells to gemcitabine/5-FU plus PPAR $\gamma$ ligand, compared with the vector cells treated with gemcitabine/5-FU alone or gemcitabine/5-FU plus PPAR $\gamma$ ligand. We thought that the higher levels of PPAR $\gamma$ in chemoresistant cells, potentially make the cells more susceptible to the ligand therapy. This suggests that the high levels of PPAR $\gamma$ expressed in PC are involved in gemcitabine and 5-FU sensitivity, and also indicates that overexpression of PPAR $\gamma$ may be an adaptive response which mediates chemosensitivity in PC cells. Further characterization of the mechanisms by how PPAR $\gamma$ enables chemosensitivity in PC is still unclear, and further studies are needed to clarify the therapeutic potential of PPAR $\gamma$ for this deadly disease.

\section{Acknowledgements}

This study was supported by the National High-tech R\&D Program (863 Program), China (no. 2012AA02A506); and the Science and Technology Department of Guangdong Province, China (no. 2012B031800088).

\section{References}

1. Pliarchopoulou K and Pectasides D: Pancreatic cancer: current and future treatment strategies. Cancer Treat Rev 35: 431-436, 2009.

2. Ramon Torrell JM and Serra Majem L: Descriptive epidemiology of cancer of the stomach in Catalonia (1983-1986). Gac Sanit 4: 76-77, 1990 (In Spanish).

3. Siegel R, Naishadham D and Jemal A: Cancer statistics, 2012. CA Cancer J Clin 62: 10-29, 2012.

4. Bardeesy N and DePinho RA: Pancreatic cancer biology and genetics. Nat Rev Cancer 2: 897-909, 2002.

5. Michalik L, Auwerx J, Berger JP, et al: International Union of Pharmacology. LXI. Peroxisome proliferator-activated receptors. Pharmacol Rev 58: 726-741, 2006.

6. Kersten S, Desvergne B and Wahli W: Roles of PPARs in health and disease. Nature 405: 421-424, 2000.

7. Zhu YJ, Crawford SE, Stellmach V, et al: Coactivator PRIP, the peroxisome proliferator-activated receptor-interacting protein, is a modulator of placental, cardiac, hepatic, and embryonic development. J Biol Chem 278: 1986-1990, 2003.

8. Lemberger T, Desvergne B and Wahli W: Peroxisome proliferator-activated receptors: a nuclear receptor signaling pathway in lipid physiology. Annu Rev Cell Dev Biol 12: 335-363, 1996.

9. Auboeuf D, Rieusset J, Fajas L, et al: Tissue distribution and quantification of the expression of mRNAs of peroxisome proliferator-activated receptors and liver $X$ receptor-alpha in humans: no alteration in adipose tissue of obese and NIDDM patients. Diabetes 46: 1319-1327, 1997.

10. Kliewer SA, Forman BM, Blumberg B, et al: Differential expression and activation of a family of murine peroxisome proliferator-activated receptors. Proc Natl Acad Sci USA 91: 7355-7359, 1994.

11. Bishop-Bailey D and Hla T: Endothelial cell apoptosis induced by the peroxisome proliferator-activated receptor (PPAR) ligand 15-deoxy-Delta12, 14-prostaglandin J2. J Biol Chem 274: 17042-17048, 1999.

12. Xin X, Yang S, Kowalski J and Gerritsen ME: Peroxisome proliferator-activated receptor gamma ligands are potent inhibitors of angiogenesis in vitro and in vivo. J Biol Chem 274: 9116-9121, 1999.

13. Marcus SL, Miyata KS, Zhang B, Subramani S, Rachubinski RA and Capone JP: Diverse peroxisome proliferator-activated receptors bind to the peroxisome proliferator-responsive elements of the rat hydratase/dehydrogenase and fatty acyl-CoA oxidase genes but differentially induce expression. Proc Natl Acad Sci USA 90: 5723-5727, 1993.

14. Kliewer SA, Umesono K, Mangelsdorf DJ and Evans RM: Retinoid $X$ receptor interacts with nuclear receptors in retinoic acid, thyroid hormone and vitamin D3 signalling. Nature 355: 446-449, 1992.

15. Ramachandran L, Manu KA, Shanmugam MK, et al: Isorhamnetin inhibits proliferation and invasion and induces apoptosis through the modulation of peroxisome proliferatoractivated receptor gamma activation pathway in gastric cancer. J Biol Chem 287: 38028-38040, 2012.

16. Bishop-Bailey D: PPARs and angiogenesis. Biochem Soc Trans 39: 1601-1605, 2011.

17. Jung UJ, Torrejon $\mathrm{C}$, Chang CL, Hamai H, Worgall TS and Deckelbaum RJ: Fatty acids regulate endothelial lipase and inflammatory markers in macrophages and in mouse aorta: a role for PPARgamma. Arterioscler Thromb Vasc Biol 32: 2929-2937, 2012.

18. Tontonoz P, Hu E and Spiegelman BM: Stimulation of adipogenesis in fibroblasts by PPAR gamma 2, a lipid-activated transcription factor. Cell 79: 1147-1156, 1994. 
19. Gelman L, Fruchart JC and Auwerx J: An update on the mechanisms of action of the peroxisome proliferator-activated receptors (PPARs) and their roles in inflammation and cancer. Cell Mol Life Sci 55: 932-943, 1999.

20. Fajas L, Debril MB and Auwerx J: Peroxisome proliferatoractivated receptor-gamma: from adipogenesis to carcinogenesis J Mol Endocrinol 27: 1-9, 2001.

21. Wang T, Xu J, Yu X, Yang R and Han ZC: Peroxisome proliferator-activated receptor gamma in malignant diseases. Crit Rev Oncol Hematol 58: 1-14, 2006.

22. Kristiansen G, Jacob J, Buckendahl AC, et al: Peroxisome proliferator-activated receptor gamma is highly expressed in pancreatic cancer and is associated with shorter overall survival times. Clin Cancer Res 12: 6444-6451, 2006.

23. Watkins G, Douglas-Jones A, Mansel RE and Jiang WG: The localisation and reduction of nuclear staining of PPARgamma and PGC-1 in human breast cancer. Oncol Rep 12: 483-488, 2004.

24. Segawa Y, Yoshimura R, Hase T, et al: Expression of peroxisome proliferator-activated receptor (PPAR) in human prostate cancer Prostate 51: 108-116, 2002.

25. Theocharis S, Kanelli H, Politi E, et al: Expression of peroxisome proliferator activated receptor-gamma in non-small cell lung carcinoma: correlation with histological type and grade. Lung Cancer 36: 249-255, 2002.

26. Zhang GY, Ahmed N, Riley C, et al: Enhanced expression of peroxisome proliferator-activated receptor gamma in epithelial ovarian carcinoma. Br J Cancer 92: 113-119, 2005.

27. Sasaki T, Fujimoto Y, Tsuchida A, Kawasaki Y, Kuwada Y and Chayama K: Activation of peroxisome proliferator-activated receptor gamma inhibits the growth of human pancreatic cancer Pathobiology 69: 258-265, 2001.

28. Hahn WC, Dessain SK, Brooks MW, et al: Enumeration of the simian virus 40 early region elements necessary for human cell transformation. Mol Cell Biol 22: 2111-2123, 2002.

29. Soumaoro LT, Uetake H, Higuchi T, Takagi Y, Enomoto M and Sugihara K: Cyclooxygenase-2 expression: a significant prognostic indicator for patients with colorectal cancer. Clin Cancer Res 10: 8465-8471, 2004

30. Asou H, Verbeek W, Williamson E, et al: Growth inhibition of myeloid leukemia cells by troglitazone, a ligand for peroxisome proliferator activated receptor gamma, and retinoids. Int J Oncol 15: 1027-1031, 1999.

31. Zang C, Liu H, Posch MG, et al: Peroxisome proliferatoractivated receptor gamma ligands induce growth inhibition and apoptosis of human B lymphocytic leukemia. Leuk Res 28 : 387-397, 2004
32. Sato H, Ishihara S, Kawashima K, et al: Expression of peroxisome proliferator-activated receptor (PPAR)gamma in gastric cancer and inhibitory effects of PPARgamma agonists. Br J Cancer 83: 1394-1400, 2000.

33. Sarraf P, Mueller E, Smith WM, et al: Loss-of-function mutations in PPAR gamma associated with human colon cancer. Mol Cell 3: 799-804, 1999 .

34. Mueller E, Sarraf P, Tontonoz P, et al: Terminal differentiation of human breast cancer through PPAR gamma. Mol Cell 1: 465-470, 1998 .

35. Ogino S, Shima K, Baba Y, et al: Colorectal cancer expression of peroxisome proliferator-activated receptor gamma (PPARG, PPARgamma) is associated with good prognosis. Gastroenterology 136: 1242-1250, 2009.

36. Inoue K, Kawahito $\mathrm{Y}$, Tsubouchi $\mathrm{Y}$, et al: Expression of peroxisome proliferator-activated receptor gamma in renal cell carcinoma and growth inhibition by its agonists. Biochem Biophys Res Commun 287: 727-732, 2001.

37. Eibl G, Wente MN, Reber HA and Hines OJ: Peroxisome proliferator-activated receptor gamma induces pancreatic cancer cell apoptosis. Biochem Biophys Res Commun 287: 522-529, 2001.

38. Farrow B and Evers BM: Activation of PPARgamma increases PTEN expression in pancreatic cancer cells. Biochem Biophys Res Commun 301: 50-53, 2003.

39. Itami A, Watanabe G, Shimada $Y$, et al: Ligands for peroxisome proliferator-activated receptor gamma inhibit growth of pancreatic cancers both in vitro and in vivo. Int J Cancer 94: 370-376, 2001.

40. Katz MH, Fleming JB, Lee JE and Pisters PW: Current status of adjuvant therapy for pancreatic cancer. Oncologist 15: 1205-1213, 2010.

41. Squadroni M and Fazio N: Chemotherapy in pancreatic adenocarcinoma. Eur Rev Med Pharmacol Sci 14: 386-394, 2010.

42. Duxbury MS, Ito H, Zinner MJ, Ashley SW and Whang EE: Inhibition of SRC tyrosine kinase impairs inherent and acquired gemcitabine resistance in human pancreatic adenocarcinoma cells. Clin Cancer Res 10: 2307-2318, 2004.

43. Leung L, Radulovich N, Zhu CQ, et al: Lipocalin2 promotes invasion, tumorigenicity and gemcitabine resistance in pancreatic ductal adenocarcinoma. PLoS One 7: e46677, 2012

44. Awasthi N, Zhang C, Ruan W, Schwarz MA and Schwarz RE: BMS-754807, a small-molecule inhibitor of insulin-like growth factor-1 receptor/insulin receptor, enhances gemcitabine response in pancreatic cancer. Mol Cancer Ther 11: 2644-2653, 2012.

45. Wang H, Pei W, Luan Q, et al: A feasibility study on gene therapy of pancreatic carcinoma with Ad-PUMA. Cancer Biol Ther 13: 712-719, 2012. 